\title{
Momordica charantia (bitter melon) inhibits primary human adipocyte differentiation by modulating adipogenic genes
}

\author{
Pratibha V Nerurkar*1, Yun-Kung Lee ${ }^{1}$ and Vivek R Nerurkar²
}

\begin{abstract}
Background: Escalating trends of obesity and associated type 2 diabetes (T2D) has prompted an increase in the use of alternative and complementary functional foods. Momordica charantia or bitter melon (BM) that is traditionally used to treat diabetes and complications has been demonstrated to alleviate hyperglycemia as well as reduce adiposity in rodents. However, its effects on human adipocytes remain unknown. The objective of our study was to investigate the effects of BM juice (BMJ) on lipid accumulation and adipocyte differentiation transcription factors in primary human differentiating preadipocytes and adipocytes.
\end{abstract}

Methods: Commercially available cryopreserved primary human preadipocytes were treated with and without BMJ during and after differentiation. Cytotoxicity, lipid accumulation, and adipogenic genes mRNA expression was measured by commercial enzymatic assay kits and semi-quantitative RT-PCR (RT-PCR).

Results: Preadipocytes treated with varying concentrations of BMJ during differentiation demonstrated significant reduction in lipid content with a concomitant reduction in mRNA expression of adipocyte transcription factors such as, peroxisome proliferator-associated receptor $\gamma$ (PPARY) and sterol regulatory element-binding protein 1c (SREBP-1c) and adipocytokine, resistin. Similarly, adipocytes treated with BMJ for $48 \mathrm{~h}$ demonstrated reduced lipid content, perilipin mRNA expression, and increased lipolysis as measured by the release of glycerol.

Conclusion: Our data suggests that BMJ is a potent inhibitor of lipogenesis and stimulator of lipolysis activity in human adipocytes. BMJ may therefore prove to be an effective complementary or alternative therapy to reduce adipogenesis in humans.

\section{Background}

In the United States, approximately 127 million adults are overweight (body mass index, BMI $>25 \mathrm{~kg} / \mathrm{m}^{2}$ ) while more than 60 million are classified as obese $(\mathrm{BMI}>30 \mathrm{~kg} /$ $\mathrm{m}^{2}$ ), and about 9 million as severely obese (BMI $>40 \mathrm{~kg} /$ $\mathrm{m}^{2}$ ). In the last two decades, the prevalence of overweight individuals has increased by $40 \%$ (from $46.0 \%$ to $64.5 \%$ ) and the prevalence of obesity has risen by $110 \%$ (from $14.5 \%$ to $30.5 \%$ ) [1]. Obesity is also associated with metabolic disorders such as type 2 diabetes (T2D), which is the second leading cause of preventable death in the United States [2].

* Correspondence: pratibha@hawaii.edu

1 Laboratory of Metabolic Disorders and Alternative Medicine, Department of Molecular Biosciences and Bioengineering, College of Tropical Agriculture and Human Resources, University of Hawaii at Manoa, Honolulu, Hawaii 96822 USA Full list of author information is available at the end of the article
Adipose tissue is a critical endocrine organ that is innately involved in regulating not only obesity, but also metabolic processes such as, insulin resistance and type-2 diabetes mellitus (T2DM) [3,4]. Adipogenesis involves development of preadipocytes to mature adipocytes with the accumulation of lipid droplets, increase in fat cell size (hypertrophy), as well as increase in cell number or hyperplasia and plays an important role in obesity. Among the various transcription factors that promote preadipocyte differentiation and influence adipogenesis, peroxisome proliferator-activated receptor $\gamma(\operatorname{PPAR} \gamma)$ is considered the "master regulator of adipogenesis" $[5,6]$. Other adipogenic transcription factors include the CCAAT/enhancer binding proteins $(\mathrm{C} / \mathrm{EBP} \alpha, \mathrm{C} / \mathrm{EBP} \beta$ and $\mathrm{C} / \mathrm{EBP} \delta$ ) and sterol regulatory element-binding protein 1c (SREBP-1c) [7-9]. Similarly, lipolysis or lipid 
mobilization in adipocytes results from breakdown of adipose triacylglycerols (TAG) into nonesterified fatty acids (NEAF) and glycerol and involves not only lipases and TAG hydrolases, but also lipid-droplet coating proteins such as perilipin $[10,11]$. Besides adipocyte transcription factors, adipocyte-secreted factors (adipocytokines) also play an important role in primary human preadipocyte differentiation [12]. Adipocytokine resistin, a 12-kDa peptide, is increased along with PPAR $\gamma$ during the differentiation of 3T3-L1 adipocytes [13] and primary human adipocytes [12]. Overall, an appropriate balance between adipogenesis and lipolysis is therefore crucial for the proper functioning of adipose tissue, which plays an important role in obesity and associated metabolic functions.

Successful treatment of obesity usually requires multiple interventions such as exercise programs, diet, behavioral modification and pharmacotherapy [14-20]. Escalating trends of obesity has resulted in a renewed interest in the use of functional foods including herbs and alternative medicine [21]. Momordica charantia, commonly known as bitter melon (BM), is widely cultivated in Asia, East-Africa and South America and extensively used in folk medicines as a remedy for diabetes and its complications, specifically in India, Southeast Asia, Africa and South America [22]. Animal studies indicate that $\mathrm{BM}$ juice $(\mathrm{BMJ})$ was also effective in reducing weight gain, possibly due to reduced adipose hypertrophy, inhibition of lipogenic genes and increased plasma catecholamines [23-26]. However, effects of BMJ on human adipocyte differentiation are unknown. Therefore, the goal of our project was to elucidate the effects of BMJ on lipid accumulation, lipid mobilization, and expression of adipocyte transcription factors and adipocytokine, in primary human adipocytes. It was observed that BMJ significantly reduced lipid accumulation and increased lipolysis in primary human adipocytes, with a concomitant reduction in PPAR $\gamma, \mathrm{SREBP}-1 \mathrm{c}$, perilipin, and resistin genes expression. These studies are critical as they lay the foundation to identify molecular targets and antiobesity effects of bitter melon for future clinical trials.

\section{Methods}

\section{Preparation of Bitter Melon Juice (BMJ)}

Chinese variety of young BM (which had not ripened and turned yellow/orange) was obtained from local farmer's market, washed and deseeded. BMJ was extracted according to the previously published protocol [26,27]. In brief, young, green BM fruits were deseeded and pulp was discarded. Juice was prepared in a regular household juicer and centrifuged at $4,500 \mathrm{rpm}$ at $4^{\circ} \mathrm{C}$ for $30 \mathrm{~min}$. About $8,000 \mathrm{~g}$ of deseeded BM fruit yielded $3,500 \mathrm{~mL}$ of $\mathrm{BMJ}$. BMJ supernatant was aliquoted and stored at $-80^{\circ} \mathrm{C}$ until further analysis. Each aliquot was frozen and thawed only once. The BM variety was verified and identified by ethnobotanist, Dr. Will McClatchey and voucher specimen was deposited at official herbaria, University of Hawai'i at Manoa, Herbarium (HAW), and labeled as PratibhaBM0001 and PratibhaBM0002 [26].

\section{Primary Human Adipocyte Cultures}

Cryopreserved primary human preadipocytes (catalog \# SP-F-SL, lot \# SL0028) were obtained from ZenBio (Research Triangle Park, NC) and cultured according to the manufacturer' instructions. The pooled primary preadipocytes were derived from subcutaneous adipose tissues of six female donors with an average age of 43 years and average BMI of $27.25 \mathrm{~kg} / \mathrm{m}^{2}$. Preadipocytes were maintained in "Preadipocyte Medium" (cat \# PM-1, ZenBio) and upon confluence, cells were plated in either 96-well, 24-well or 6-well plates at a density of 13,500, 62,500 , or 333,333 cells/well, respectively. Two days after plating, cells were differentiated using "Differentiation Medium" (catalog \# DM-2, ZenBio) and considered as Day ' 0 '. Media was changed every two days, 2, 4, 6, 8, 10 and 12. Cells were harvested for analysis on day 14, after which the cells accumulated lipid droplets and were considered as mature adipocytes. In one set of experiments, preadipocytes were treated with BMJ during differentiation from day ' 0 ' to day 12 and harvested on day 14 for various analysis. In another set of experiments, when cells were fully differentiated into adipocytes after 14 days, they were treated with $0.5,1.0$ and $2 \%$ BMJ for 24 and $48 \mathrm{~h}$.

\section{Cytotoxicity Measurements}

At the end of experimental periods, viability of cells treated with varying BMJ concentrations $(0.5,1.0,2.0,5.0$ and $10.0 \%, \mathrm{v} / \mathrm{v}$ ) was determined using the ATPlite Luminescence Detection Assay System (Cat\# 6016941, Perkin Elmer, Boston, MA) according to the manufacturer's protocol. To determine cell cytotoxicity, media was harvested to measure the release of lactate dehydrogenase (LDH) using CytoTox-ONE Homogeneous Membrane Integrity Assay (Cat\# G7891, Promega) as described previously $[27,28]$. Cellular ATP levels are a marker for cell viability since ATP is present in all metabolically active cells and the concentration declines rapidly in apoptotic or necrotic cells.

\section{Oil Red Staining}

Oil Red 'O' staining of adipocytes was performed according to published protocols [29]. In brief, after washing in ice-cold PBS cells were fixed overnight in $10 \%$ formalin, washed with water, and stained with $0.3 \%$ oil red for $1 \mathrm{~h}$. After thorough washings with water and evaporation of excess water, oil red was extracted in isopropyl alcohol and the absorbance was monitored at $490 \mathrm{~nm}$ using Wal- 
lac Victor ${ }^{2} 1420$ Multilabel Counter (PerkinElmer Life Sciences, Boston, MA).

\section{Cellular Triglyceride (TG) Analysis}

Preadipocytes were treated either during differentiation, or after differentiation, with varying concentrations of $\mathrm{BMJ}$ as mentioned above. Cells were washed with icecold PBS and lysed with $0.5 \mathrm{~N}$ sodium hydroxide $(\mathrm{NaOH})$. Cellular TG content was measured using the Infinity TG Liquid Stable Reagent commercial kit (Thermo-DMA, St Louisville, CO, U.S.A.), and the absorbance was read at $540 \mathrm{~nm}$ using Wallac Victor ${ }^{2} 1420$ Multilabel Counter. TG values were normalized to $\mathrm{mg}$ of protein as determined by the Bradford method according to the manufacturer's instructions (Bio-Rad Laboratories, Hercules, CA).

\section{Determination of Lipolysis}

Lipolysis was measured as a function of free glycerol released into the medium. In brief, 14 days after differentiation, primary human adipocytes were treated with 0.5 , 1 and $2 \%$ BMJ for 24 and $48 \mathrm{~h}$. Free glycerol was measured using the commercial glycerol free reagent and glycerol standards according to manufacture's protocol (Sigma, St. Louis, MO).

\section{Semi-Quantitation of mRNA gene expression}

To evaluate the mechanism of reduced adipocyte differentiation and lipid accumulation, mRNA gene expression of peroxisome proliferator-activated receptor gamma (PPAR $\gamma)$, sterol regulatory element-binding protein -1 (SREBP-1) and resistin genes were determined by semiquantitative reverse transcriptase-PCR (RT-PCR) in preadipocytes treated with varying concentrations of BMJ during differentiation. To further delineate the mechanisms underlying lipolysis, perilipin mRNA expression was determined in adipocytes treated with BMJ for $48 \mathrm{~h}$. Total RNA was extracted using TRIzol reagent (TEL-TEST, Inc., Friendswood, TX). Two $\mu \mathrm{g}$ of RNA was reverse transcribed into complementary DNA (cDNA) and gene expression levels were quantified by two-step RT-PCR using the primer pairs and cycling conditions described in Table 1. Various cycling conditions were initially used to standardize the gene expression profile in the log phase of amplification. Final cycling condition was decided based on half of maximum saturation of the amplicons. The PCR amplicon was size-fractionated on a $2 \%$ agarose gel and visualized with ethidium bromide staining. mRNA expressions of various genes were semi- quantified using the Kodak 1D image analysis software that captures the intensity of the amplicons and calculates the pixel counts by normalizing against the background. The intensities of the amplicon were then expressed as a ratio of the gene of interest against a housekeeping gene, GAPDH.

\section{Statistical Analysis}

All statistical analysis was performed using GraphPad Prism, Prism 5 for Windows, version 5.01. Data were expressed as mean values \pm SEM. A one-way or two-way ANOVA model was used to compare means between the groups. Each sample was analyzed twice. Post hoc pairwise multiple comparisons were evaluated using the Tukey's Multiple Comparison test or Bonferroni posttest, after ANOVA. Results were considered significant at $\mathrm{p}<0.05$.

\section{Results}

BMJ reduces triglyceride (TG) content and increases lipolysis in primary human adipocytes

$0.5,1$ and $2 \%$ BMJ (v/v) was well tolerated and was not toxic to primary human preadipocytes or adipocytes, while higher concentrations of BMJ (5 and 10\%) was cytotoxic as indicated by significantly increased LDH release and reductions in cellular ATP levels. Preadipocytes treated with $5 \%$ and $10 \% \mathrm{BMJ}$ during differentiation demonstrated a significant, $31 \%$ and $57 \%$, increase in $\mathrm{LDH}$ release when treated, respectively (Figure 1A). Treatment with $5 \%$ BMJ was marginally toxic ( $19 \%$ reduction), while $10 \%$ BMJ significantly reduced cell viability by $47 \%$ (Figure $1 \mathrm{~B}$ ) as measured by cellular ATP levels.

Among adipocytes treated with varying BMJ concentrations for 24 and $48 \mathrm{~h}$, the trends in cellular ATP levels and LDH release were similar to the BMJ-treated differentiating adipocytes. Both, 5\% and 10\% BMJ significantly increased LDH release by $21 \%$ and $51 \%$ (Figure 1C). Figure 1D demonstrates that 5\% BMJ non-significantly reduced cellular ATP by $20 \%$, while $10 \%$ BMJ significantly reduced ATP levels by 32\% ( $<<0.05)$ after $48 \mathrm{~h}$. We therefore used $0.5,1$ and $2 \% \mathrm{BMJ}(\mathrm{v} / \mathrm{v})$ in all our subsequent experiments.

Effects of BMJ on cellular differentiation and lipid contents are demonstrated in Figure 2. In contrast to control adipocytes (Figure $2 \mathrm{~A}$ ), cells treated with $0.5 \% \mathrm{BMJ}$ (Figure 2B), $1 \% \mathrm{BMJ}$ (Figure 2C) and 2\% BMJ (Figure 2D) during differentiation demonstrate a significant reduction in lipid content as observed by reduced oil red staining (Figures $2 \mathrm{~A}$ to $2 \mathrm{D}$ ). Figure $2 \mathrm{E}$ demonstrates the amount of total lipid content of cells as measured by organic solvent extraction of oil ' $\mathrm{O}$ ' red from cells. A significant $(\mathrm{p}<0.05)$ dose-dependent reduction in adipocyte differentiation (25 to $70 \%$ ) was observed in cells treated with BMJ as indicated by reduction in oil 'O' red staining (Figure 2E). Inhibition of differentiation was also accompanied by a significant reduction $(\mathrm{p}<0.05)$ in cellular TG levels by 40 to $70 \%$ in cells treated with $\mathrm{BMJ}$ during differentiation, as compared to control untreated adipocytes (Figure 3A). Similarly, when adipocytes were treated with BMJ for 24 $\mathrm{h}$ and $48 \mathrm{~h}$, cellular TG were significantly reduced $(\mathrm{p}<$ 0.05 ) by 20 to $50 \%$ (Figure 3B) with a concomitant 
Table 1: Oligonucleotide primer sequences used in RT-PCR

\begin{tabular}{|c|c|c|c|}
\hline Target Gene & Primer sequence & Cycling condition & Size (bp) \\
\hline PPAR $\gamma 2$ & $\begin{array}{l}\text { Forward 5'-GCATGGTGCCTTCGCTGATGC-3' } \\
\text { Reverse 5'-AGGCCTGTTGTAGAGCTGGGT-3' }\end{array}$ & $\begin{array}{l}95^{\circ} \mathrm{C} / 5 \mathrm{~min} \\
95^{\circ} \mathrm{C} / 1 \mathrm{~min}, 55^{\circ} \mathrm{C} / 1 \mathrm{~min} \\
72^{\circ} \mathrm{C} / 1 \mathrm{~min}, 72^{\circ} \mathrm{C} / 7 \mathrm{~min} \\
4^{\circ} \mathrm{C} \text { hold, } 33 \text { cycles }\end{array}$ & 340 \\
\hline SREBP-1C & $\begin{array}{l}\text { Forward 5'-TTGCGCAAGGCCATCGACTACATT-3' } \\
\text { Reverse 5'-ACAAGGGGCTGCTCTGGAAAGGTG-3' }\end{array}$ & $\begin{array}{l}94^{\circ} \mathrm{C} / 5 \min \\
94^{\circ} \mathrm{C} / 1 \mathrm{~min}, 55^{\circ} \mathrm{C} / 1 \mathrm{~min} \\
72^{\circ} \mathrm{C} / 1 \mathrm{~min}, 72^{\circ} \mathrm{C} / 7 \mathrm{~min} \\
4^{\circ} \mathrm{C} \text { hold, } 26 \text { cycles }\end{array}$ & 238 \\
\hline Perilipin & $\begin{array}{l}\text { Forward 5'-TGGAGACTGAGGAGAAGAAG-3' } \\
\text { Reverse 5'-ATGTGAGAGGGGAGATGG-3' }\end{array}$ & $\begin{array}{l}94^{\circ} \mathrm{C} / 1.5 \mathrm{~min} \\
94^{\circ} \mathrm{C} / 45 \mathrm{sec}, 52^{\circ} \mathrm{C} / 1.5 \mathrm{~min} \\
72^{\circ} \mathrm{C} / 1 \mathrm{~min}, 72^{\circ} \mathrm{C} / 7 \mathrm{~min} \\
4^{\circ} \mathrm{C} \text { hold }, 23 \text { cycles }\end{array}$ & 120 \\
\hline Resistin & $\begin{array}{l}\text { Forward 5'-TGGTGGTGGTGGCTGTCCTGG-3' } \\
\text { Reverse 5'-GAGTGAGATGTGGTCTGGGCG-3' }\end{array}$ & $\begin{array}{l}95^{\circ} \mathrm{C} / 2 \mathrm{~min} \\
95^{\circ} \mathrm{C} / 45 \mathrm{sec}, 55^{\circ} \mathrm{C} / 1.5 \mathrm{~min} \\
72^{\circ} \mathrm{C} / 45 \mathrm{sec}, 72^{\circ} \mathrm{C} / 7 \mathrm{~min} \\
4^{\circ} \mathrm{C} \text { hold, } 39 \text { cycles }\end{array}$ & 145 \\
\hline GAPDH & $\begin{array}{l}\text { Forward 5'-AGTCAGCCGCATCTTCTITTG-3' } \\
\text { Reverse 5'-CTCCTGGAAGGGAGATGG-3' }\end{array}$ & Condition adjusted as per the target gene & 298 \\
\hline
\end{tabular}

increase in lipolysis up to 70\% (Figure 3C) $(\mathrm{p}<0.05)$. Treatment of adipocytes with $2 \% \mathrm{BMJ}$ induced maximum TG reduction and lipolysis after $48 \mathrm{~h}$, Figure $3 \mathrm{~B}$ and $3 \mathrm{C}$, respectively, but without any significant changes in cellular morphology.

\section{BMJ reduces mRNA expression of PPARY, SREBP-1c and resistin}

Adipocyte transcription factors such as PPAR $\gamma$ and SREBP-1c, as well as adipocytokine, resistin, play a crucial role in adipocyte differentiation, adipogenesis, and accumulation of cellular lipid droplets. The fact that BMJ reduced adipocyte differentiation prompted us to investigate the effects of BMJ on mRNA expression of PPAR $\gamma$, SREBP-1c and resistin. Preadipocytes treated with $0.5,1$ or $2 \%$ BMJ during differentiation demonstrated a significant reduction $(\mathrm{p}<0.005)$ in PPAR $\gamma$ mRNA expression, 50 to $80 \%$, as compared to control untreated adipocytes (Figure 4). Similarly, a significant $(\mathrm{p}<0.05)$ dose-dependent reduction in SREBP-1c mRNA expression was observed, further confirming an anti-adipogenic effect of BMJ (Figure 5). However, reduction in mRNA expression of resistin gene in preadipocytes treated with 0.5 and $1.0 \%$ BMJ during differentiation was not significant as compared to untreated control cells. In contrast, treatment with $2 \%$ BMJ demonstrated a significant reduction of $45 \%(p<0.05)$ in resistin gene expression (Figure 6). Overall, maximum inhibition of adipocyte differentiation and transcription factors was observed with $2 \% \mathrm{BMJ}$.

\section{BMJ inhibits perilipin mRNA expression}

Formation of lipid droplets in adipocytes as well as lipolysis is regulated by a membrane protein surrounding the lipid droplets, perilipin, which is also a downstream target of PPAR $\gamma$ in adipocytes. BMJ-associated reduction in cellular TG (Figure 3B) and increased lipolysis (Figure $3 C$ ) in adipocytes, was accompanied by a significant reduction $(\mathrm{p}<0.05)$ of perilipin gene $\mathrm{mRNA}$ expression in adipocytes treated with BMJ for up to $48 \mathrm{~h}$ (Figure 7). There was no significant change in morphological appearance of the cells or cell death, but reduction in lipid size droplets.

\section{Discussion}

Bitter melon is used to treat diabetes and its complications in traditional Chinese and Ayurvedic medicine. We and others have demonstrated that besides improving glucose and lipid metabolism [26,30-32], BMJ is also effective in improving hyperlipidemia in diabetic and obese rodents as well as reduces body weights in mice fed high-fat diet [24,25,33]. However, the effects of bitter melon on human adipocytes have not been investigated. Transition of undifferentiated fibroblastic preadipocytes into mature adipocytes involves differential regulation of adipogenic genes as well as lipid accumulation. Increase in fat mass is a result of not only increase in adipocyte number due to proliferation, but also induction of differentiation that stimulates mitotic clonal expansion and 


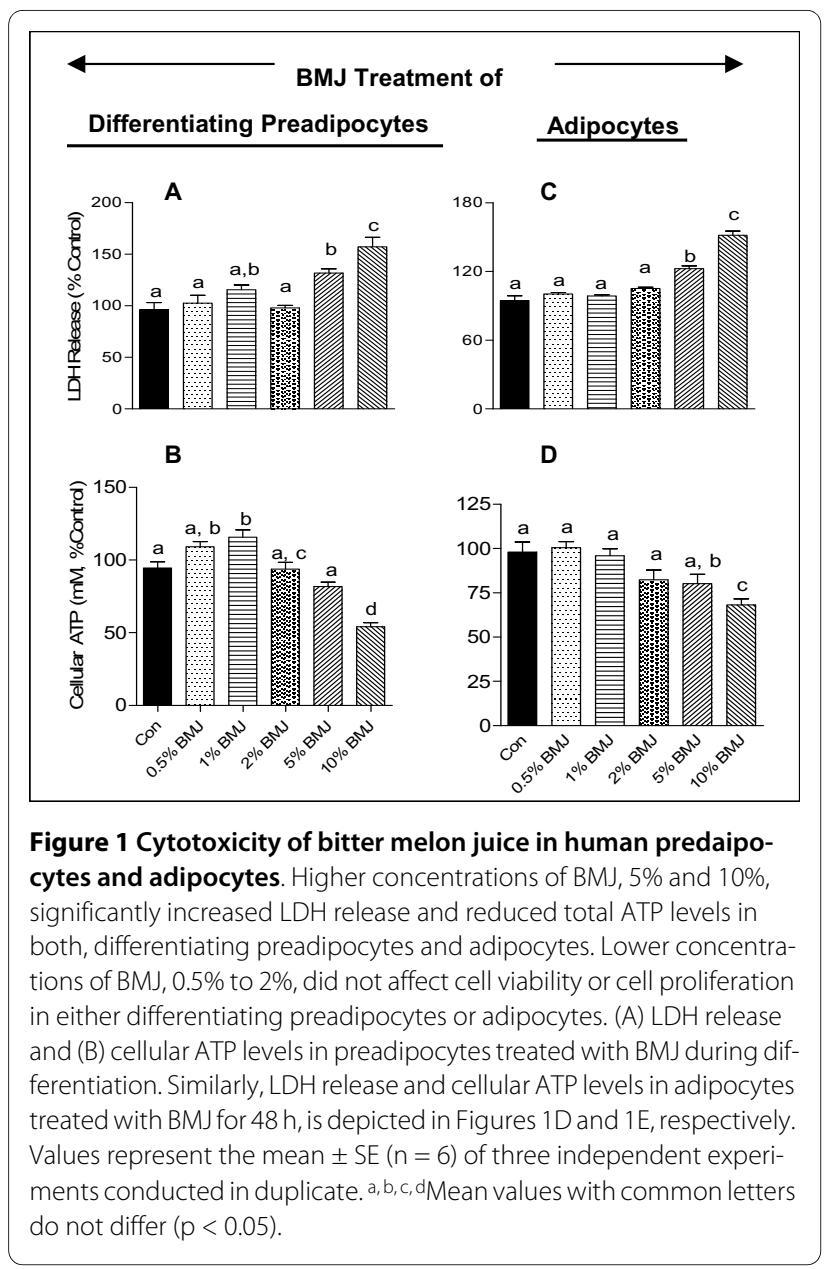

irreversible commitment to differentiation [34]. Therefore, reduction in fat mass during weight loss may involve inhibition of adipogenic process and lipid accumulation due to dedifferentiation, lipid mobilization (lipolysis) and/or programmed cell death (apoptosis). Higher concentrations of BMJ at $5 \%$ and $10 \%$ demonstrate significant reduction in cell viability as indicated by reduced cellular ATP levels and increased LDH release. It is therefore possible that higher concentration of BMJ induces apoptosis in maturing preadipocytes and adipocytes, which requires further investigation.

During normal adipogenesis, growth arrest after confluency is followed by mitotic expansion and adipogenic signals to induce differentiation and lipid accumulation [35]. Mitotic clonal growth is accomplished by increased expression of CCAAT/enhancer binding protein beta $(\mathrm{C} /$ EBP $\beta$ ) which further stimulates the expression of two transcription factors, C/EBP $\alpha$ and PPAR $\gamma$ involved in adipogenesis and lipogenesis [36]. Our data indicates that lower concentrations of BMJ (0.5\% to $2 \%)$ has no effect on growth arrest or cell death, but may possibly promote dedifferentiation of maturing preadipocytes via reduction in PPARY mRNA gene expression and reduction in lipo-

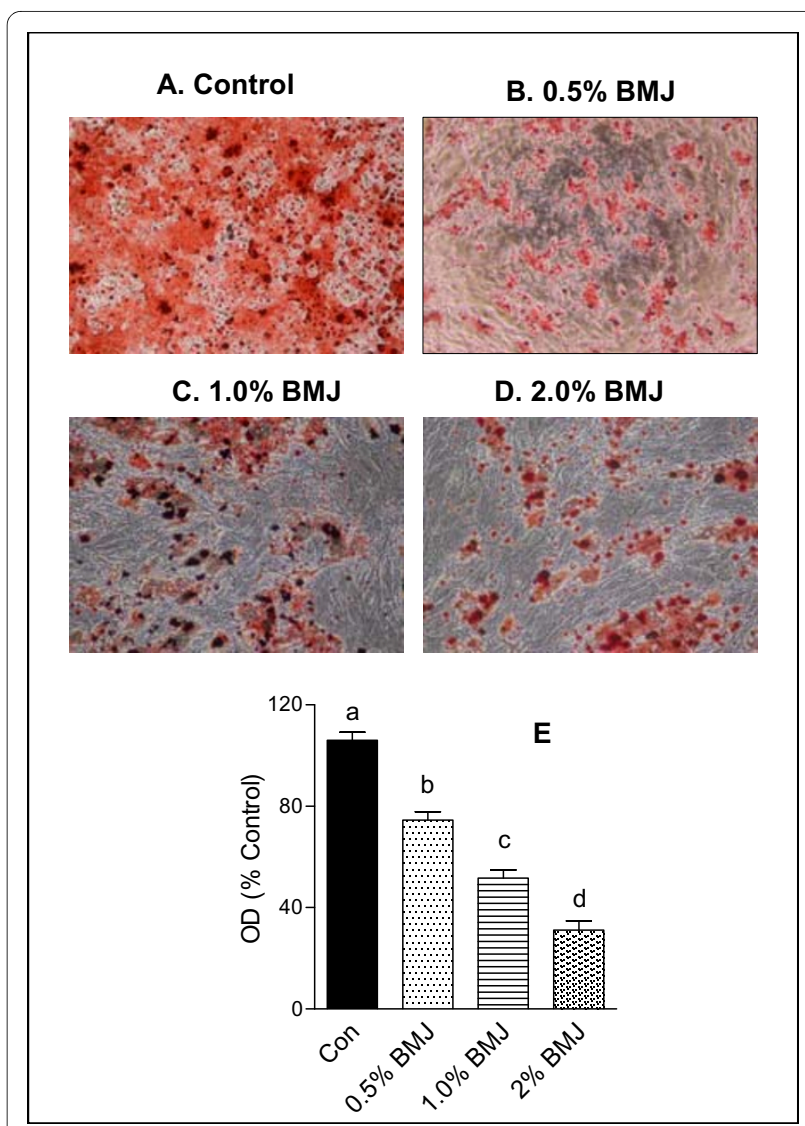

Figure 2 Effect of bitter melon juice on cellular lipid droplets. Total cellular lipid contents were significantly reduced in preadipocytes undergoing differentiation when treated with varying concentrations of BMJ (Figures 2A - 2C). Light microscopic pictures of oil red 'O' staining in untreated control adipocytes (A), and preadipocytes treated with - $0.5 \% \mathrm{BMJ}(\mathrm{B}), 1 \% \mathrm{BMJ}(\mathrm{C})$ or $2 \% \mathrm{BMJ}(\mathrm{D})$, during differentiation (40x magnification). Figure $1 \mathrm{E}$ depicts degree of preadipocyte differentiation during treatment as measured by total amount of extracted oil "O" red. Values represent the mean $\pm S E(n=6)$ of three independent experiments conducted in duplicate. ${ }^{a}, b, c, d$ Mean values with common letters do not differ $(p<0.05)$.

gensis. Although we did not measure $\mathrm{C} / \mathrm{EBP} \alpha$, it is possible that effects of BMJ are mediated upstream via $\mathrm{C} /$ EBP $\beta$. To our knowledge, this is a first study to elucidate the effects of BMJ on primary human adipocyte differentiation and analyze the adipogenic gene expressions. PPAR $\gamma$, a nuclear hormone receptor, plays a critical role in peripheral glucose homeostasis and energy metabolism and has been implicated in modulating adipogenesis and insulin sensitivity in vivo. Anti-diabetic agents such as rosiglitazone are PPAR $\gamma$ agonist and improve glucose metabolism by increasing adipogenesis thereby leading to secondary weight gain [37]. Recent studies indicate that partial PPAR $\gamma$ antagonism by various plant extracts may be beneficial in improving insulin sensitivity and may also inhibit adipocyte differentiation and lipid accumulation $[34,38,39]$. In the present studies, BMJ significantly inhib- 


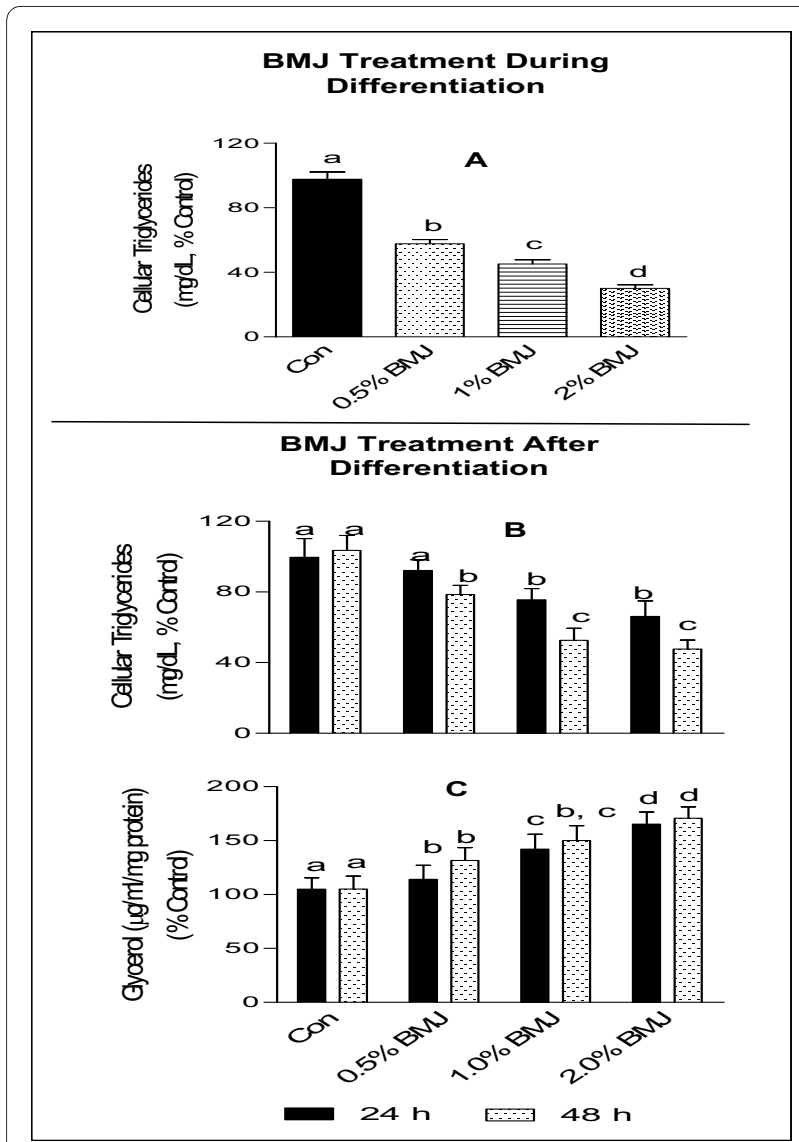

Figure 3 Effect of bitter melon juice on cellular triglyceride mass. Cellular triglyceride levels were reduced in (A) differentiating preadipocytes treated with varying concentrations of BMJ during differentiation and (B) adipocytes treated with varying concentrations of BMJ for 24 and $48 \mathrm{~h}$. Figure $3 \mathrm{C}$ depicts the increased release of glycerol into the media, when adipocytes were treated with varying concentration of $\mathrm{BMJ}(0.5 \%$ to $2 \%, \mathrm{v} / \mathrm{v})$ for 24 and $48 \mathrm{~h}$. Values represent the mean $\pm \mathrm{SE}$ $(n=6)$ of three independent experiments conducted in duplicate. $a, b$,

$c$, dMean values with common letters do not differ $(p<0.05)$.

ited adipogenesis in differentiating preadipocytes with a concomitant reduction in PPAR $\gamma$ gene expression.

We further observed that SREBP-1c, another regulator of lipid homeostasis and adipogenesis [40] was significantly reduced by BMJ in primary human adipocytes with a simultaneous reduction in cellular lipid content indicated by reduced oil 'O' red staining. Studies by Huang et al. indicated that BM powder, prepared from whole fruit, inhibited adipocyte hypertrophy in dietinduced obese (DIO) rats possibly due to reduction in the expression of lipogenic genes including fatty acid synthase (FAS), acetyl CoA carboxylase (ACC 1), lipoprotein lipase (LPL) and adipocyte fatty acid-binding protein (aP2) in epididymal fat, which are down-stream targets of SREBP-1c [25]. However, Huang et al. did not observe any effects on either PPARY or SREBP-1c mRNA expression in the adipose tissue of rats fed HFD and BM, but

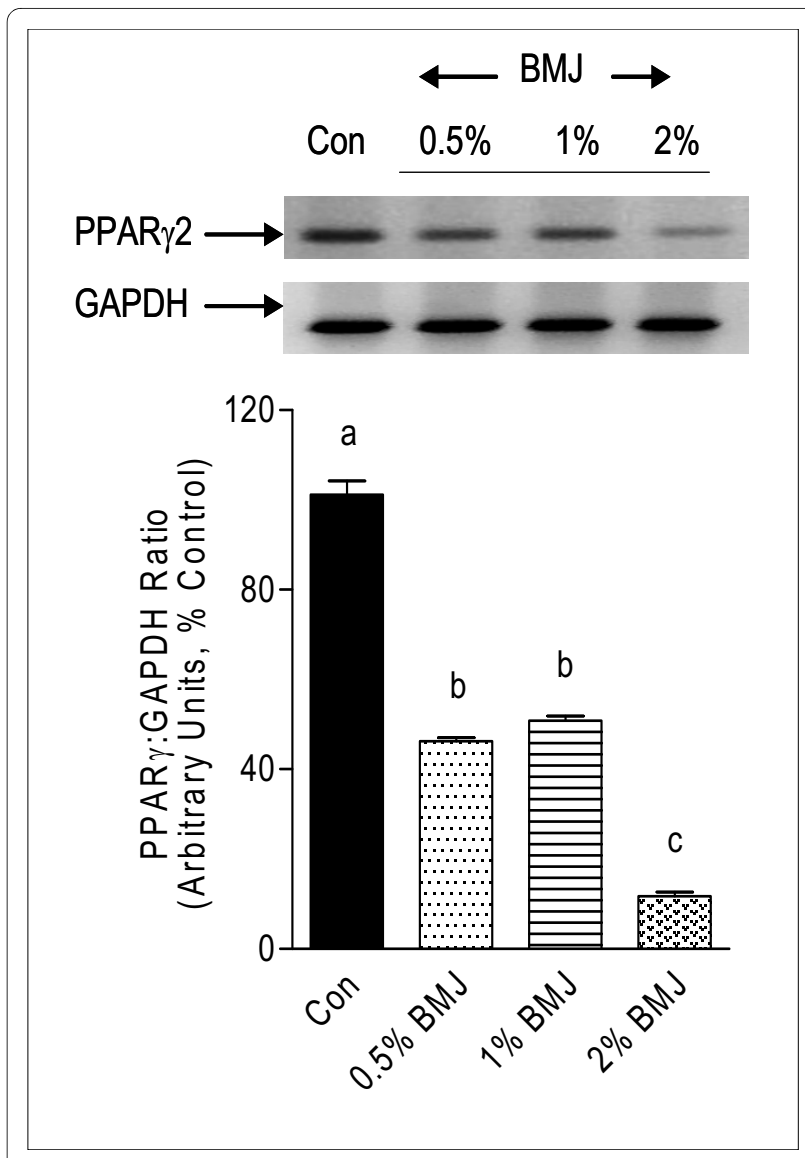

Figure 4 Effect of bitter melon juice on PPARy mRNA expression. Differentiating preadipocytes treated with varying concentrations of BMJ demonstrate a significant reduction in PPARY mRNA gene expression. Bar graphs depict the densitometry scans of PPARy amplicons (348-bp) and are expressed as a ratio to GAPDH amplicon (298-bp) intensity. Data are expressed as a percentage of the control (set as 100\%) and the values represent the mean \pm SE $(n=6)$ of three independent experiments analyzed in duplicate. $a, b, c$ Mean values with common letters do not differ $(p<0.05)$.

suggested possible effects of BM on either the protein levels or post-transcriptional modifications of these genes [25].

Adipocytokines such as leptin and adiponectin, involved in food intake, energy metabolism and weight gain have been demonstrated to be regulated by BMJ in cell culture and rodent studies [41,42]. It has been recently demonstrated that adipocytokine, resistin, is involved in human adipocyte differentiation [12]. In our study, BMJ significantly reduced mRNA expression of resistin in primary human adipocytes treated during differentiation. Similarly, Shih et al. [42] also demonstrated a significant reduction in adipose resistin expression in mice fed HFD with BMJ. Among obese individuals, the increased plasma resistin has been demonstrated to positively correlate with changes in BMI and visceral fat as well as mRNA expression in abdominal fat $[43,44]$. The 


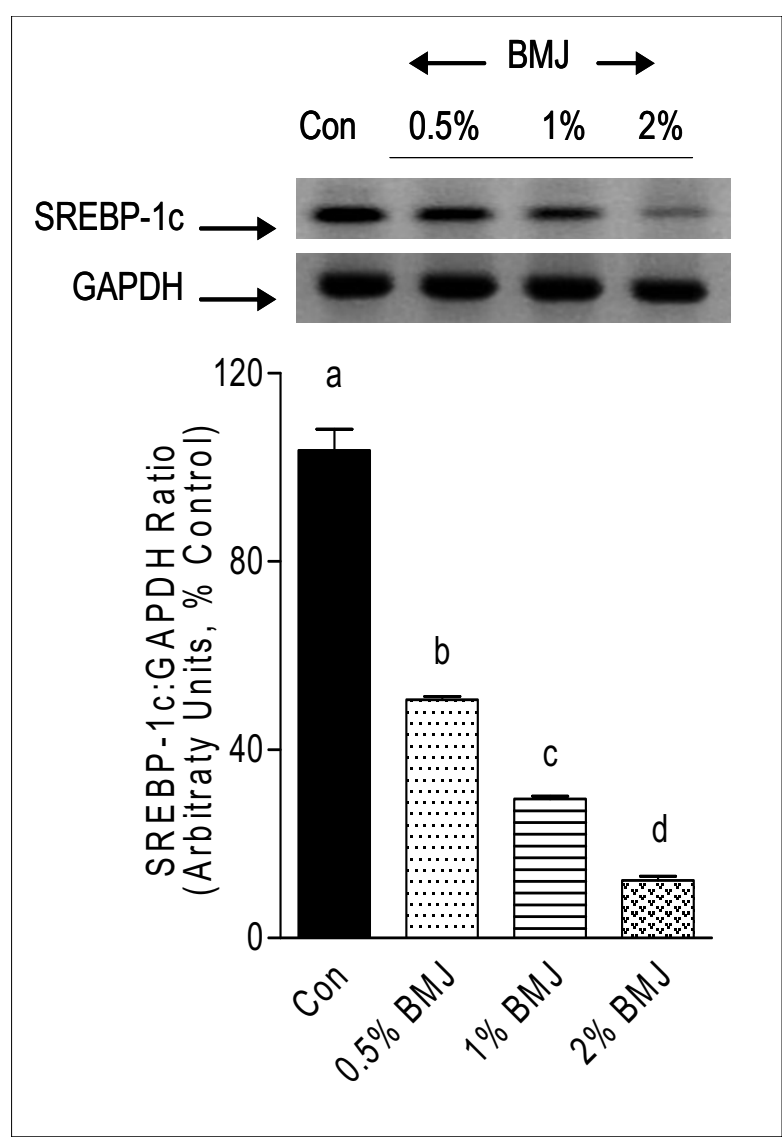

Figure 5 Effect of bitter melon juice on SREBP-1c mRNA expression. Differentiating preadipocytes treated with varying concentrations of BMJ $(0.5 \%$ to $2 \%, \mathrm{v} / \mathrm{v})$ demonstrate a significant reduction in SREBP-1 1 mRNA gene expression. Bar graphs depict the densitometry scans of SREBP gene amplicons (238-bp) and are expressed as a ratio to GAPDH amplicon (298-bp) intensity. Data are expressed as a percentage of the control (set as 100\%) and the values represent the mean $\pm S E(n=6)$ of three independent experiments analyzed in duplicate. ${ }^{a}, b, c$ Mean values with common letters do not differ $(p<0.05)$.

fact that plasma resistin levels are reduced in subjects with moderate weight loss [45] and our data indicating reduced resistin expression in primary human adipocytes, supports the hypothesis that BMJ possess an antiadipogeneic potential in humans.

Additional mechanisms for reduced adiposity in BMJfed rodents may include increased levels of plasma catecholamines that are known to promote lipolysis in adipose tissue [24]. Perilipins are the most abundant lipid droplet-specific proteins that influence adipocyte TG storage and accumulation by regulating lipolysis [46]. They are synthesized on free ribosomes rather than on endoplasmic reticulum-bound ribosomes and require post-translational assembly onto lipid droplets [46]. Perilipins also regulate lipolysis by modulating the access of hormone sensitive lipases (HSL) to the surface of lipid droplet [47]. Although post-transcriptional phosphoryla-

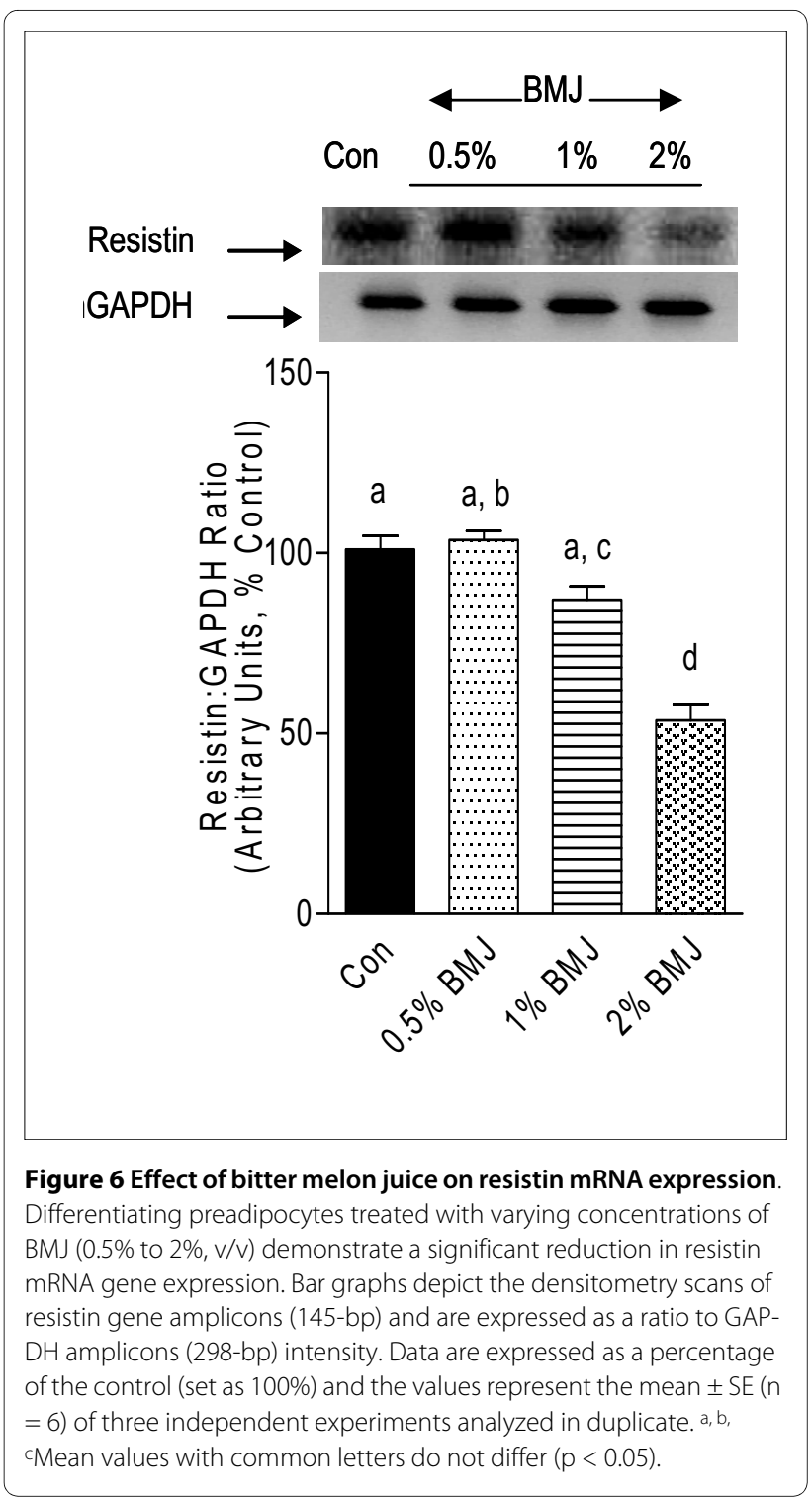

tion of perilipin via G-protein coupled receptor-activated protein kinase A (PKA) is associated with increased lipolysis in human adipocytes [48], studies with TNF $\alpha$ indicate that adipocyte lipolysis was also associated with inhibition of perilipin mRNA expression [49]. Similarly, our data also indicate that lipolytic activity of BMJ is possibly associated with significant inhibition of perilipin mRNA expression. Since perilipin is a down-stream target of PPAR $\gamma$, it is highly possible that BMJ may interfere with ligand-binding domain of PPAR $\gamma$ or may inhibit endogenous PPAR $\gamma$ ligands and block PPAR $\gamma$ target genes. Alternatively, we cannot overrule the possibility that BMJ can directly phosphorylate perilipin proteins by activation of G-protein coupled receptors.

The range of $\mathrm{BMJ}$ concentrations used in the current study is comparable to those used in earlier studies [26]. However, the exact effective and safe dose of BMJ for 


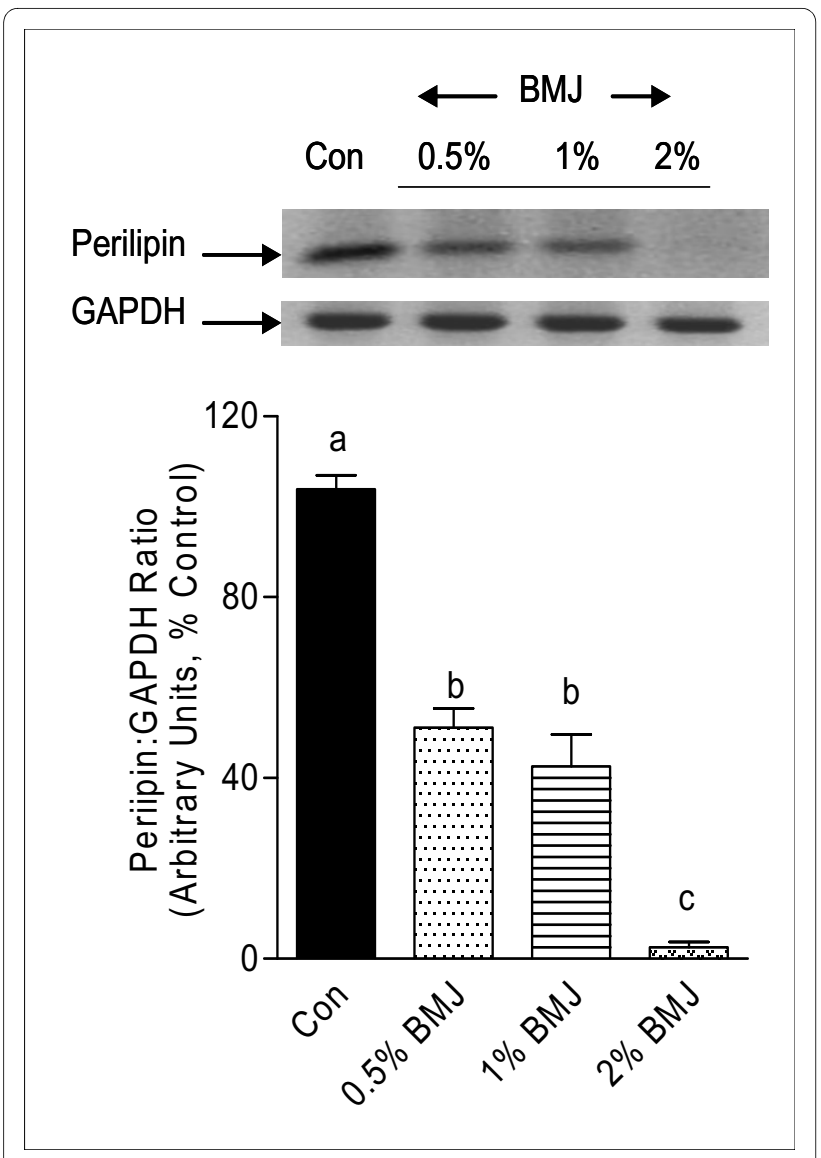

Figure 7 Effect of bitter melon juice on perilipin mRNA expression. Adipocytes treated with varying concentrations of $\mathrm{BMJ}(0.5 \%$ to $2 \%, v / v)$ demonstrate a significant reduction in perilipin mRNA gene expression. Bar graphs depict the densitometry scans of 120-bp perilipin gene amplicons and are expressed as a ratio to GAPDH amplicon (298-bp) intensity. Data are expressed as a percentage of the control (set as 100\%) and the values represent the mean \pm SE $(n=6)$ of three independent experiments analyzed in duplicate. a, b, cMean values with common letters do not differ $(p<0.05)$.

human consumption is unknown and requires further clinical evaluation. BMJ contains many active chemicals including charantin (a steroid glycoside), polypeptide "p" or plant insulin (a 166 residue insulin mimetic peptide) [50], glycosides such as mormordin, vitamin C, carotenoids, flavanoids and polyphenols [51,52]. Our unpublished observations and those by Islam et. al. [53] indicate that BMJ contains various polyphenols including quercetin and gallic acids. Quercetin has been demonstrated to inhibit adipogenesis and induce apoptosis in 3T3-L1 mouse adipocytes [54,55], while gallic acid is known to increase the number of early and late apoptotic 3T3-L1 cells in culture via loss of mitochondrial membrane potential [56]. We therefore speculate that insulinmimetic peptides as well as polyphenols such as quercetin and gallic acid may in part be responsible for anti-adi- pogenic properties of BMJ. Recent studies indicate that cucurbutanoid compounds are the active principals of BMJ which possess hypoglycemic properties [57], but the exact active ingredients possessing hypolipidemic properties are unknown.

Overall our studies demonstrate that BMJ inhibits primary human adipocyte differentiation by reducing PPAR $\gamma$, SREBP and perilipin mRNA gene expression and by increasing lipolysis. In animal studies, although BMJ reduced adiposity, Shih et al. demonstrated that adipose PPAR $\gamma$ mRNA expression was significantly increased in DIO mice fed BMJ extracts and HFD, as compared to both, HFD-fed and control mice [42], while Huang et al. did not observe any effects on adipose lipolysis in rats fed HFD with BM [25]. These differences are possibly due to differences in the model system (primary human adipocytes vs. rodents), BM preparations and/or experimental conditions.

A few clinical studies have investigated the anti-diabetic effects of BMJ in humans [58-62], however, longterm studies testing the effects of BMJ on glucose and lipid metabolism, body weight as well as identifying the pharmacokinetics and effective dose of BMJ is warranted, before it can be recommended as an effective alternative and/or complementary therapy. Regardless of its therapeutic effects, use of BMJ with other hypoglycemic or hypolipidemic agents must be performed with caution and under medical supervision due to its hypoglycemic properties $[63,64]$ and excessive consumption must be avoided due to possible side effects such as diarrhea [61].

\section{Conclusions}

Bitter melon was effective in reducing lipid accumulation in primary human adipocytes by regulating adipogenic transcription factors and adipocytokine gene expression. Future studies are warranted to test the effects of BM consumption on weight loss and body fat accumulation in humans.

\section{Abbreviations \\ ACC 1: acetyl CoA carboxylase; aP2: adipocyte fatty acid-binding protein; BM: bitter melon; BMI: body mass index; BMJ: bitter melon juice; C/EBP: CCAAT/ enhancer binding proteins; DIO: diet-induced obesity; FAS: fatty acid synthase; Insig-1: insulin-induced gene 1; LPL: lipoprotein lipase; NEFA: non-esterified fatty acids; PPARY: peroxisome proliferator-associated receptor $\gamma$; RT-PCR: reverse transcriptase-PCR; SREBP-1c: sterol regulatory element-binding protein 1c; T2D: type 2 diabetes; TAG: triacylglycerol; TG: triglycerides.}

\section{Competing interests}

The authors declare that they have no competing interests.

\section{Authors' contributions}

PVN conceived and designed the study as well as analyzed and interpreted the data, and wrote the manuscript. Y-KL performed RT-PCR and enzymatic assays for data acquisition and VRN was involved in data analysis and critically revising the manuscript for important intellectual content. PVN has primary responsibility for final content. Authors have read and approved the final manuscript. 


\section{Acknowledgements}

We thank Ms. Laurel Pearson for technical assistance with primary human adipocyte cell cultures and Mr. Ryuei Sato for his assistance with oil 'O' red images. We also thank Dr. Will McClatchey, Professor, Department of Botany, University of Hawaii, for identifying the varieties of bitter melon, voucher preparation and deposition into the herbarium.

This work was supported partially by US Public Health Service grants from the National Institutes of Health $(\mathrm{NIH})$, Research Centers in Minority Institutions (G12RR003061) and the Hawaii Community Foundation (200112061 and 20041652) to PVN.

\section{Author Details}

'Laboratory of Metabolic Disorders and Alternative Medicine, Department of Molecular Biosciences and Bioengineering, College of Tropical Agriculture and Human Resources, University of Hawaii at Manoa, Honolulu, Hawaii 96822 USA and 2 Retrovirology Research Laboratory, Department of Tropical Medicine, Medical Microbiology and Pharmacology, John A. Burns School of Medicine, University of Hawaii at Manoa, Honolulu, Hawaii 96813 USA

Received: 11 March 2010 Accepted: 29 June 2010

Published: 29 June 2010

\section{References}

1. Low S, Chin MC, Deurenberg-Yap M: Review on epidemic of obesity. Ann Acad Med Singapore 2009, 38:57-59.

2. Scheen AJ: Antiobesity pharmacotherapy in the management of type 2 diabetes. P.J.L.: Diabetes Metab Res Rev 2000, 16:114-124.

3. Adipocyte Biology. 4th International Conference on Nutrition and HIV infection and the 2nd European Workshop on Lipodystrophy; April, 19-21; Cannes, France 2001

4. Gregoire FM: Adipocyte differentiation: From fibroblast to endocrine cell. Exp Biol Med (Maywood) 2001, 226:997-1002.

5. Wakabayashi K, Okamura M, Tsutsumi S, Nishikawa NS, Tanaka T, Sakakibara I, Kitakami J, Ihara S, Hashimoto Y, Hamakubo T, et al: The peroxisome proliferator-activated receptor gamma/retinoid $\mathrm{X}$ receptor alpha heterodimer targets the histone modification enzyme PR-Set7/ Setd8 gene and regulates adipogenesis through a positive feedback loop. Mol Cell Biol 2009, 29:3544-3555.

6. Tontonoz P, Spiegelman BM: Fat and beyond: the diverse biology of PPARgamma. Annu Rev Biochem 2008, 77:289-312.

7. Vernochet $C$, Peres SB, Davis KE, McDonald ME, Qiang L, Wang H, Scherer $\mathrm{PE}$, Farmer SR: C/EBPa and the corepressors $\mathrm{CtBP} 1 / 2$ regulate repression of select visceral white adipose genes during the induction of the brown phenotype in white adipocytes by PPAR" agonists. Mol Cell Biol 2009. doi:10.1128/MCB.01899-08

8. Inoue J, Kumagai H, Terada T, Maeda M, Shimizu M, Sato R: Proteolytic activation of SREBPs during adipocyte differentiation. Biochem Biophys Res Commun 2001, 283:1157-1161

9. Kim JB, Spiegelman BM: ADD1/SREBP1 promotes adipocyte differentiation and gene expression linked to fatty acid metabolism. Genes Dev 1996, 10:1096-1107.

10. Tansey JT, Sztalryd C, Gruia-Gray J, Roush DL, Zee JV, Gavrilova O, Reitman ML, Deng CX, Li C, Kimmel AR, Londos C: Perilipin ablation results in a lean mouse with aberrant adipocyte lipolysis, enhanced leptin production, and resistance to diet-induced obesity. Proc Natl Acad SCi USA 2001, 98:6494-6499.

11. Tansey JT, Sztalryd C, Hlavin EM, Kimmel AR, Londos C: The central role of perilipin a in lipid metabolism and adipocyte lipolysis. IUBMB Life 2004, 56:379-385.

12. Ye ZW, Wu XM, Jiang JG: Expression changes of angiotensin II pathways and bioactive mediators during human preadipocytes-visceral differentiation. Metabolism 2009.

13. Steppan CM, Brown EJ, Wright CM, Bhat S, Banerjee RR, Dai CY, Enders GH, Silberg DG, Wen X, Wu GD, Lazar MA: A family of tissue-specific resistinlike molecules. Proc Natl Acad Sci USA 2001, 98:502-506.

14. Sheperd TM: Effective management of obesity. The J Family Practice 2003, 52:1-13

15. Isidro ML, Cordido F: Drug treatment of obesity: established and emerging therapies. Mini Rev Med Chem 2009, 9:664-673.

16. Tsai AG, Wadden TA: Treatment of Obesity in Primary Care Practice in the United States: A Systematic Review. J Gen Intern Med 2009.
17. Baker MK, Byrne TK, Feldmann ME: Surgical treatment of obesity. Prim Care 2009, 36:417-427.

18. Bloomgarden ZT: Obesity: mediators and treatment approaches. Diabetes Care 2009, 32:e48-52

19. Boissonneault GA: Obesity: the current treatment protocols. JAAPA 2009, 22(16):18-19.

20. Shewmake RA, Huntington MK: Nutritional treatment of obesity. Prim Care 2009, 36:357-377

21. Hasani-Ranjbar S, Nayebi N, Larijani B, Abdollahi M: A systematic review of the efficacy and safety of herbal medicines used in the treatment of obesity. World J Gastroenterol 2009, 15:3073-3085.

22. Grover JK, Yadav S, Vats V: Medicinal plants of India with anti-diabetic potential. J Ethnopharmacol 2002, 81:81-100.

23. Chen Q, Chan LLY, Li ETS: Bitter melon (Momordica charantia) reduces adiposity, lowers serum insulin and normalizes glucose tolerance in rats fed a high diet. J Nutr 2003, 133:1088-1093.

24. Chen Q, Li ET: Reduced adiposity in bitter melon (Momordica charantia) fed rats is associated with lower tissue triglyceride and higher plasma catecholamines. Br J Nutr 2005, 93:747-754.

25. Huang $\mathrm{HL}$, Hong YW, Wong YH, Chen YN, Chyuan JH, Huang CJ, Chao PM: Bitter melon (Momordica charantia L.) inhibits adipocyte hypertrophy and down regulates lipogenic gene expression in adipose tissue of diet-induced obese rats. Br J Nutr 2008, 99:230-239.

26. Nerurkar PV, Lee YK, Motosue M, Adeli K, Nerurkar VR: Momordica charantia (bitter melon) reduces plasma apolipoprotein B-100 and increases hepatic insulin receptor substrate and phosphoinositide-3 kinase interactions. Br J Nutr 2008, 100:751-759.

27. Nerurkar PV, Pearson L, Efird JT, Adeli K, Theriault AG, Nerurkar VR: Microsomal triglyceride transfer protein gene expression and ApoB secretion are inhibited by bitter melon in HepG2 cells. J Nutr 2005, 135:702-706.

28. Nerurkar PV, Dragull K, Tang CS: In vitro toxicity of kava alkaloid, pipermethystine, in HepG2 cells compared to kavalactones. Toxicol Sci 2004, 79:106-111.

29. Shi Y, Liu Y, Murdin A, Raudonikiene-Mancevski A, Ayach B, Yu Z, Fantus G, Liu P: Chlamydophila pneumoniae inhibits differentiation of progenitor adipose cells and impairs insulin signaling. J Infect Dis 2008, 197:439-448.

30. Chaturvedi P: Role of Momordica charantia in maintaining the normal levels of lipids and glucose in diabetic rats fed a high-fat and lowcarbohydrate diet. Br J Biomed Sci 2005, 62:124-126.

31. Tan MJ, Ye JM, Turner N, Hohnen-Behrens C, Ke CQ, Tang CP, Chen T, Weiss HC, Gesing ER, Rowland A, et al: Antidiabetic activities of triterpenoids isolated from bitter melon associated with activation of the AMPK pathway. Chem Biol 2008, 15:263-273.

32. Sridhar MG, Vinayagamoorthi R, Arul Suyambunathan V, Bobby Z, Selvaraj $\mathrm{N}$ : Bitter gourd (Momordica charantia) improves insulin sensitivity by increasing skeletal muscle insulin-stimulated IRS-1 tyrosine phosphorylation in high-fat-fed rats. Br J Nutr 2008, 99:806-812.

33. Chan LL, Chen Q, Go AG, Lam EK, Li ET: Reduced adiposity in bitter melon (Momordica charantia)-fed rats is associated with increased lipid oxidative enzyme activities and uncoupling protein expression. J Nutr 2005, 135:2517-2523.

34. Rayalama S, Della-Feraa MA, Bailea CA: Phytochemicals and regulation of the adipocyte life cycle. J Nurtitional Biochemistry 2008, 19:717-726.

35. Umek RM, Friedman AD, Mcknight SL: CCAAT-enhancer binding protein: a component of a differentiation switch. Science 1991, 251:288-292.

36. Huang C, Zhang Y, Gong Z, Sheng X, Li Z, Zhang W, Qin Y: Berberine inhibits 3T3-L1 adipocyte differentiation through the PPARy pathway. Biochem Biophy Res Commun 2006, 348:571-578.

37. Vidhya S, Mohan V: Rosiglitazone--useful drug but has side effects. Assoc Physicians India 2002, 50:615.

38. Christensen KB, Minet A, Svenstrup H, Grevsen K, Zhang H, Schrader E, Rimbach G, Wein S, Wolffram S, Kristiansen K, Christensen LP: Identification of plant extracts with potential antidiabetic properties: effect on human peroxisome proliferator-activated receptor (PPAR) adipocyte differentiation and insulin-stimulated glucose uptake. Phytother Res 2009.

39. Freise C, Erben U, Neuman U, Kim K, Zeitz M, Somasundaram R, Ruehl M: An active extract of Lindera obtusiloba inhibits adipogenesis via sustained Wnt signaling and exerts anti-inflammatory effects in the 3T3-L1 preadipocytes. J Nutr Biochem 
40. Hsuy S-C, Huang C-J: Reduced fat mass in rats fed a high oleic acid-rich safflower oil diet is associated with changes in expression of hepatic PPARa and adipose SREBP-1c-regulated genes. J Nutr 2006, 136:1779-1785

41. Roffey BW, Atwal AS, Johns T, Kubow S: Water extracts from Momordica charantia increase glucose uptake and adiponectin secretion in 3T3-L1 adipose cells. J Ethnopharmacol 2007, 112:77-84.

42. Shih CC, Lin CH, Lin WL: Effects of Momordica charantia on insulin resistance and visceral obesity in mice on high-fat diet. Diabetes Res Clin Pract 2008, 81:134-143.

43. Azuma K, Katsukawa F, Oguchi S, Murata M, Yamazaki H, Shimada A, Saruta T: Correlation between serum resistin level and adiposity in obese individuals. Obes Res 2003, 11:997-1001.

44. McTernan PG, McTernan CL, Chetty R, Jenner K, Fisher FM, Lauer MN Crocker J, Barnett AH, Kumar S: Increased resistin gene and protein expression in human abdominal adipose tissue. 87:2407. J Clin Endocrinol Metab 2002, 87:2407-2414.

45. Valsamakis G, McTernan PG, Chetty R, Al Daghri N, Field A, Hanif W, Barnett $\mathrm{AH}, \mathrm{Kumar} \mathrm{S}$ : Modest weight loss and reduction in waist circumference after medical treatment are associated with favorable changes in serum adipocytokines. Metabolism 2004, 53:430-434.

46. Garcia A, Sekowski A, Subramanian V, Brasaemle D: The central domain is required to target and anchor perilipin A to lipid droplets. $J$ Bio/ Chem 2003, 278:625-635.

47. Souza S, Palmer H, Kang Y, Yamamoto M, Muliro K, Paulson K, Greenberg A: TNF-alpha induction of lipolysis is mediated through activation of the extracellular signal related kinase pathway in 3T3-L1 adipocytes. $J$ Cell Biochem 2003, 89:1077-1086.

48. Zhang H, Halbleib M, Ahmad F, Manganiello VC, Greenberg A: Tumor necrosis factor-a stimulates lipolysis in differentiated human adipocytes through activation of extracellular signal-related kinase and elevation of intracellular CAMP. Diabetes 2002, 51:2929-2935.

49. Ryden M, Arvidsson E, Blomqvist L, Perbeck L, Dicker A, Arner P: Targets for TNF-a-induced lipolysis in human adipocytes. Biochem Biophys Res Commun 2004, 318:168-175.

50. Khanna P, Jain SC, Panagariya A, Dixit VP: Hypoglycemic activity of polypeptide-p from a plant source. J Nat Prod 1981, 44:648-655.

51. Jantan I, Rafi IA, Jalil J: Platelet-activating factor (PAF) receptor-binding antagonist activity of Malaysian medicinal plants. Phytomedicine 2005, 12:88-92.

52. Anila L, Vijayalakshmi NR: Beneficial effects of flavonoids from Sesamum indicum, Emblica officinalis and Momordica charantia. Phytother Res 2000, 14:592-595.

53. Islam S, Jalaluddin M, Hettiarachchy NS: Physiological Functions of bitter melon varieties (Momordica charantia $\mathrm{L}$ ) in relation to polyphenolic contents. HortScience 2008, 43:1223.

54. Park HJ, Yang JY, Ambati S, Della-Fera MA, Hausman DB, Rayalam S, Baile $C A:$ Combined effects of genistein, quercetin, and resveratrol in human and 3T3-L1 adipocytes. J Med Food 2008, 11:773-783.

55. Yang JY, Della-Fera MA, Rayalam S, Ambati S, Hartzell DL, Park HJ, Baile CA: Enhanced inhibition of adipogenesis and induction of apoptosis in 3T3-L1 adipocytes with combinations of resveratrol and quercetin. Life Sci 2008, 82:1032-1039.

56. Hsu CL, Huang SL, Yen GC: Inhibitory effect of phenolic acids on the proliferation of 3T3-L1 preadipocytes in relation to their antioxidant activity. J Agric Food Chem 2006, 54:4191-4197.

57. Harinantenaina L, Tanaka M, Takaoka S, Oda M, Mogami O, Uchida M, Asakawa Y: Momordica charantia constituents and antidiabetic screening of the isolated major compounds. Chem Pharm Bull (Tokyo) 2006, 54:1017-1021.

58. Welihinda J, Karunanayake EH, Sheriff MH, Jayasinghe KS: Effect of Momordica charantia on the glucose tolerance in maturity onset diabetes. J Ethnopharmacol 1986, 17:277-282.

59. Leatherdale BA, Panesan RK, Singh G, Atkins TW, Bailey CJ, Bignell AH: Improvement in glucose tolerance due to Momordica charantia (karela). Br Med J (Clin Res Ed) 1981, 282:1823-1824.

60. Srivastava $Y$, Venkatakrishna-Bhatt $H$, Verma $Y$, et al: Antidiabetic and adaptogenic properties of Momordica charantia extract. An experimental and clinical evaluation. Phytother Res 1993, 7:285-289.

61. Basch E, Gabardi S, Ulbricht C: Bitter melon (Momordica charantia): a review of efficacy and safety. Am J Health Syst Pharm 2003, 60:356-359.
62. Tuekpe MK, Todoriki H, Sasaki S, Zheng KC, Ariizumi M: Potassium excretion in healthy Japanese women was increased by a dietary intervention utilizing home-parcel delivery of Okinawan vegetables. Hypertens Res 2006, 29:389-396.

63. Ahmed N, Hassan MR, Halder H, Bennoor KS: Effect of Momordica charantia (Karolla) extracts on fasting and postprandial serum glucose levels in NIDDM patients. Bangladesh Med Res Counc Bull 1999, 25:11-13.

64. Welihinda J, Karunanayake EH: Extra-pancreatic effects of Momordica charantia in rats. J Ethnopharmacol 1986, 17:247-255.

\section{Pre-publication history}

The pre-publication history for this paper can be accessed here: http://www.biomedcentral.com/1472-6882/10/34/prepub

doi: 10.1186/1472-6882-10-34

Cite this article as: Nerurkar et al., Momordica charantia (bitter melon) inhibits primary human adipocyte differentiation by modulating adipogenic genes BMC Complementary and Alternative Medicine 2010, 10:34

\section{Submit your next manuscript to BioMed Centra and take full advantage of:}

- Convenient online submission

- Thorough peer review

- No space constraints or color figure charges

- Immediate publication on acceptance

- Inclusion in PubMed, CAS, Scopus and Google Scholar

- Research which is freely available for redistribution

Submit your manuscript at www.biomedcentral.com/submit
C) Biomed Central 